ДИСТАНЦІЙНЕ НАВЧАННЯ ПЕДАГОГІЧНИХ ПРАЦІВНИКІВ ЗАКЛАДІВ ДОШКІЛЬНОЇ ОСВІТИ

\title{
DISTANCE TRAINING OF PEDAGOGICAL EMPLOYEES OF PRESCHOOL EDUCATION INSTITUTIONS
}

\begin{abstract}
У cmammi зазначено, що період пандемії $\epsilon$ новим етапом змін та можливостей у системі післядипломної освіти дошкільних фахівців, який потребує надання освітніх послуг дистанційно, шляхом застосування сучасних інформаційно-комунікаційних технологій. Зазначено, що необхідною умовою ефективної діяльності педагогічних працівників закладів дошкільної освіти постає розвиток його ІК-компетентності. Констатовано, що за важливості сучасних досліджень проблема розвитку ІК-компетентності кваліфрікованих педагогів закладів дошкільної освіти засобами Інтернет-простору потребує нових підходів до ії системати зації та теоретичного узагальнення. Особливої уваги потребує дослідження розвитку ІК-компетентності педагогів закладу дошкільної освіти з використанням сучасних платформ дистанційного навчання в системі післядипломної освіти.
\end{abstract}

Проведено аналітичний огляд функціональних можливостей сучасних систем дистанчійного навчання, а саме: Blackboard Inc.; Dokeos; ATutor; Cisco WebEx; Zoom; Microsoft Teams; Equity maps; EdEra;Prometheus; Moodle. Розглянуто їхні переваги й недоліки, надані рекомендації для їх вибору. Встановлено, що натепер кожна з розглянутих систем дистанційного навчання має свої переваги та недоліки, реалізує важливі для електронного навчання фрункції, але не всі забезпечують прочес дистанційного навчання в комплексі. Найголовнішими критеріями під час вибору інструментів для організації дистанційного навчання в системі післядипломної освіти мають бути відповідність поставленим методичним цілям, універсальність, зрозумілість інтерфейсу, доступність програмних засобів для різних пристроїв (персональні комп'ютери, планшети, мобільні пристрої Apple, Android тощо). Описано можливості використання систем дистанційного навчання як засобу організації навчання орахівців дошкільної освіти в післядипломній освіті. Обгрунтовано роль Навчально-наукового lнституту неперервної освіти Національного педагогічного університету імені М. П. Драгоманова в удосконаленні змісту й спроектуванні дистанційної системи Moodle з урахуванням досягнень сучасної педагогіки, з акцентом на взаємодію між педагогічними працівни ками (http://www.do.ippk.npu.edu.ua.).
Ключові слова: системи дистанційного навчання, ІК-компетентність, педагогічні працівники закладів дошкільної освіти.

The article states that the pandemic period is a new stage of changing and opportunities in the system of postgraduate education of preschool professionals, which requires the provision of educational services remotely, through the use of modern information and communication technologies. It is noted that a necessary condition for the effective operation of pedagogical employees of preschool education is the formation and development of its IR competence. It is stated that due to the importance of the modern research, the problem of development of IC competence of qualified teachers of preschool education by means of the Internet, requires new approaches of systematization and theoretical generalization. Particular attention needs to be paid to the study of the development of IC competence of preschool teachers using modern distance learning platforms in the system of postgraduate education. An analytical review of the functionality of modern distance learning systems, namely: Blackboard Inc .; Dokeos; ATutor; Cisco WebEx; Zoom; Microsoft Teams; Equity maps; EdEra, Prometheus; Moodle. It is established that today each of the considered distance learning systems has its advantages and disadvantages, realizing important functions for e-learning, but not all functions provides the process of the distance learning in the complex. The most important criteria of choosing tools for distance learning in the system of postgraduate education should be compliance with the set methodological objectives, versatility, clarity of the interface, availability of software for different devices (PCs, tablets, Apple mobile devices, Android, etc.). Their advantages and disadvantages are considered, recommendations for their choice are given. Possibilities of using distance learning systems as a means of organizing training of preschool education specialists in postgraduate education are described. The role of the Educational and Scientific Institute of Continuing Education of the National Pedagogical University M.P. Drahomanov in improving the content and design of the remote Moodle system, taking into account the achievements of modern pedagogy with emphasis on interaction between teachers. Key words: distance learning systems, IC competence, pedagogical employees of preschool education institutions.
Національного педагогічного університету імені М.П. Драгоманова
Постановка проблеми у загальному вигляді. У зв'язку з пандемією COVID-19, під час кризи, особлива увага спрямована на задоволення освітніх потреб педагогічних працівників закладів дошкільної освіти. Через це в умовах карантинних обмежень запропоновано багато рішень щодо розвитку ІК-компетенцій кваліфрікованих педагогічних працівників закладів дошкільної освіти в системі неперервної освіти. Це одночасно виклик і новий етап змін та можливостей, який потребує надання освітніх послуг дистанційно, шляхом застосування сучасних інсрормаційно-комунікаційних технологій за певними освітніми рівнями згідно з Державними стандартами освіти.

Відповідно до ситуації, в якій сьогодні опинилася Україна, до педагогів закладів дошкільної освіти пред'являються нові вимоги. До нововведень відноситься: застосування новітніх ІКТ в освітньому процесі (розвиток мобільних технологій, поява освітніх віртуальних ігрових технологій, використання 
соціальних мереж, створення відкритого електронного контенту та ін.); своєчасне оновлення змісту освіти; створення, підтримка та удосконалення інорормаційно-освітнього середовища закладу дошкільної освіти або його окремих елементів.

У дійсності існують основні протиріччя, що полягають у невідповідності рівня професійнопедагогічної підготовленості сучасного педагога дошкільної освіти, його готовності до організації дистанційної освіти і застосування інфрормаційнокомунікаційних технологій в педагогічному процесі закладу дошкільної освіти та розвитку особистісного профресійного потенціалу і вимог, які пред'являються до нього в професійній діяльності відповідно до викликів сучасності.

Нині з упевненістю можна сказати, що необхідною умовою ефективної діяльності дошкільних педагогів постає орормування та розвиток їхньої ІК-компетентності. Водночас це інтенсифрікує та стимулює неперервну освіту фрахівців дошкільної освіти.

Аналіз останніх досліджень і публікацій 3 питань теорії і практики інформатизації освіти в сучасному науковому дискурсі свідчить про актуалізацію зазначеної проблеми. Загальні аспекти використання Інтернет-технологій у педагогічній освіті висвітлено в роботах А. Андрєєва, І. Зимньої, Г. Козлакової, С. Мушер, Е. Полат, А. Себрант, А. Семенова, Ю. Татур, В. Філіппова та інших. Важливе значення для нашого наукового пошуку мають результати досліджень 3 використання інорормаційних та комп'ютерних технологій у педагогічному процесі (Р. Вільямс, Б. Гершунський, В. Глушков, А. Єршов, К. Маклін, Ю. Машбиця, C. Пейперта, Є. Полат тощо); формування і розвитку особистості педагога в інформаційному суспільстві (В. Бондар, І. Зязюн, Н. Кузьміна, Н. Мойсеюк, Н. Ничкало, С. Сисоєва та ін).; з розвитку професійної компетентності у неперервній педагогічній освіті (С. Вершловський, Л. Даниленко, Г. Єльникова, Ю. Кулюткін, В. Маслов, Н. Ничкало, В. Олійник, В. Онушкін, В. Пікельна, Н. Протасова, Л. Пуховська, М. Романенко, В. Семиченко, Т. Сущенко, П. Худоминський, Т. Шамова та ін.).

Виділення невирішених раніше частин загальної проблеми. За важливості сучасних досліджень проблема розвитку ІК-компетентності кваліфрікованих педагогів закладів дошкільної освіти засобами Інтернет-простору потребує нових підходів до ії систематизації та теоретичного узагальнення. Особливої уваги потребує дослідження розвитку ІК-компетентності педагогів закладу дошкільної освіти з використанням зробленого аналізу сучасних платфрорм дистанційного навчання в системі післядипломної освіти.

Звідси метою статті стало вивчення та узагальнення платформ дистанційного навчання як інноваційних засобів, які сприяють розвитку
ІК-компетентності педагога закладу дошкільної освіти в системі післядипломної освіти.

Виклад основного матеріалу. Нові вимоги до фрахівців спонукають сучасного педагогічного працівника закладу дошкільної освіти адаптуватися до загальносвітових тенденцій розвитку IКT в освітній системі, які надають можливості в пошуку, відборі, обробці та зберіганні інфрормації, брати участь у створенні та впровадженні нового змісту освіти, нести відповідальність за результати своєї професійної діяльності.

Так, у Законі «Про основні засади розвитку інформаційного суспільства в Україні на 2007-2015 роки» виокремлено стратегічні цілі, a саме: «забезпечення комп'ютерної та інорормаційної грамотності населення, насамперед шляхом створення системи освіти, орієнтованої на використання новітніх IКТ у формуванні всебічно розвиненої особистості; створення загальнодержавних інформаційних систем». Стратегічним напрямом визначено: «надання кожній людині можливості для здобуття знань, умінь і навичок 3 використанням IKT під час навчання, виховання та професійної підготовки; створення умов для забезпечення комп'ютерної та інформаційної грамотності всіх верств населення, створення системи мотивацій щодо впровадження і використання IKT для фрормування широкого попиту на такі технології в усіх сорерах життя суспільства» [1].

Принагідно зазначимо, що особливу роль у вирішенні зазначених цілей відіграє дистанційне навчання як індивідуалізований процес набуття знань, умінь, навичок і способів пізнавальної діяльності людини, який відбувається в основному за опосередкованої взаємодії віддалених один від одного учасників навчального процесу в спеціалізованому середовищі, яке фрунціонує на базі сучасних психолого-педагогічних та інорормаційно-комунікаційних технологій [2].

Дистанційне навчання педагогічних працівників закладів дошкільної освіти має ряд переваг: звільняє від необхідності відвідувати освітній заклад у визначений розкладом час; дає можливість отримати освіту всім тим, хто велику частину дня зайнятий на роботі, 3 дітьми або із сім'єю; здобувати освіту паралельно з побудовою кар'єри; перебувати у відпустці по догляду за дитиною; отримувати знання, не виїжджаючи за межі своєї країни, області, міста; можливість отримати освіту особам, які мають медичні обмеження для отримання освіти за традиційними формами, особам з особливими потребами. Найбільш перспективним і цілеспрямовано організованим середовищем для розвитку ІК-компетентності педагогів закладів дошкільної освіти є система післядипломної педагогічної освіти.

Нам імпонує думка С. Семчук, згідно з якою інорорматизація освітнього процесу в закладі вищої освіти підвищує якість підготовки спеціа- 
ліста, підвищує їхній рівень самоорганізації і відповідальності, вдосконалює рівень комп'ютерної грамотності, надає можливість більш вільно орієнтуватися в сучасному житті загалом та у сорері професійної діяльності зокрема [3, с. 34].

Зауважимо, що в системі післядипломної освіти завжди була можливість використовувати дистанційне навчання, апробовувати освітні онлайн-ресурси, але завжди ці можливості використовувались лише частково. У нинішній ситуації відбуваєтьсязміщенняакцентівізтрадиційнихорорм навчання на дистанційні. Особлива роль при цьому належить платформам дистанційного навчання.

Поняття «платорорма дистанційного навчання» $€$ відносно новим терміном, метоюякогоєстворення та управління педагогічним змістом, індивідуалізоване навчання та телетьюторат. Воно включає засоби, необхідні для трьох основних користувачів - викладача, студента, адміністратора [4].

У розрізі нашого дослідження зацікавленість становлять платорорми для організації дистанційного навчання педагогічних працівників закладів дошкільної освіти, зокрема [5]:

- платформа Blackboard Inc. (www.blackboard. com), що забезпечує єдине інтерактивне середовище для навчання, взаємодії, обміну інорормацією між слухачами і викладачами закладів післядипломної освіти. Система Blackboard дозволяє здійснювати облік і контроль персональних критеріїв освітнього процесу, вводити нормативнодовідкову інформацію, накопичувати, структурувати, керувати доступом, поповнювати освітню базу, а також надавати засоби комунікації та інорормування учасників;

- Dokeos - платфрорма побудови сайтів дистанційного навчання, заснована на гілці (fork) Claroline (версії 1.4.2.). Система Dokeos має великий набір можливостей, а саме: вбудовані мультимедійні додатки для ілюстрації змісту зображеннями, анімацією, звуком і відео. Система має широкий спектр обліку і контролю успішності слухачів, можливість постійного оновлення і доповнення змісту курсів підвищення кваліфрікації. Важливою особливістю $є$ модульність - кожен модуль освітньої програми окремо можна редагувати, робити відкритим або прихованим, а також експортувати у вигляді SCORM. При цьому викладач має можливість поділу слухачів на малі групи. Використання різноманітних засобів (пошта, чат, форум, обмін фрайлами, відеоконференції) дозволяє комунікувати з викладачем та іншими слухачами;

- ATutor $€$ веб-орієнтованою системою керування навчанням слухачів курсів підвищення кваліфрікації (Learning Management System, LMS) у різноманітних форматах (Microsoft Word, PDF, DJVU). Цей проект дозволяє здійснювати тестування, проводити електронні конференції; управляти базами знань, у тому числі інтегруватися із зовнішніми інформаційними джерелами та оцінкою слухачів. У системи є ряд недоліків: відсутня підтримка української мови; система закрита для змін; для створення курсів необхідні навички програмування;

- Платформа для вебінарів Cisco WebEx - це хмарний сервіс для проведення будь-яких webконференцій, що дозволяє учасникам обмінюватися інфрормацією в будь-який момент часу 3 глобального хмарного середовища, в будь-якому місці, використовуючи комп'ютер або мобільні пристрої. Ця платорорма не дуже цікава для організації освітнього процесу в післядипломній освіті, але ми не змогли її не згадати.

- У цей складний період за лічені години система Zoom стала самою популярною платформою для проведення конфреренцій, зустрічей і вебінарів. На наш погляд, Zoom має ряд переваг. Так, слухачі можуть використовувати додаток як на комп'ютері, так і на планшеті чи смартфоні. До відеоконференції може підключитися за посиланням або ідентифікатором конореренції. Заняття можна запланувати заздалегідь, а також зробити посилання для постійних зустрічей у певний час. У платорорму вбудована інтерактивна дошка, яку можна демонструвати слухачам. Крім того, є можливість легко й швидко перемикатися 3 демонстрації екрана на інтерактивну дошку. Але під час карантину на сервіс Zoom були нарікання через низький рівень безпеки й захищеності, випадки підключення до конференцій сторонніх осіб;

- Microsoft Teams - платформа спільної роботи в Office 365 Education, що включає Word, Excel, PowerPoint, OneNote, який інтегрує слухачів, вміст і засоби. Microsoft Teams доступний 39-ма мовами. Об'єднує все в спільному робочому середовищі, яке містить чат для проведення вебінарів, семінарів, фрайлообмінник. Microsoft Teams можна використовувати на комп'ютері 3 операційною системою Windows 10 S, Windows 7+ або Mac OS X 10.10+ чи в Інтернеті, на пристрої iOS, Android, планшеті чи ноутбуці;

- Equity maps $€$ інструментом, завдяки якому можливо розкласти свої думки «по поличках», структурувати всі дані у вигляді схем, графіків та діаграм, перетворити їх на статистику. Завдяки Equity maps можливо проводити заняття у форматі лекцій, дискусійного клубу, залучати слухачів до активних обговорень;

- EdEra - соціально-публічний проект широкого спектра, з використанням IT, де розроблено різні освітні проекти, які поділено на онлайн-курси, інтерактивні підручники та спецпроекти. Так, 3 метою ознайомлення педагогів із сучасними сервісами дистанційної освіти, фрормування навичок для вибору онлайн-інструментів, Міністерство цифрової трансформації запустило безкоштовний онлайн-курс про організацію дистанційного 
навчання (освітній серіал «Карантин: онлайн-сервіси для вчителів» на сайті Дія (osvita.diia.gov.ua);

- Система Prometheus є суб'єктом надання освітніх послуг з підвищення кваліфрікації педагогічних працівників згідно з КВЕД 85.59 в Національному класифрікаторі України. Це проект масових відкритих онлайн-курсів. За допомогою системи дистанційного навчання «Prometheus», можна створити віртуальний університет та організувати дистанційне навчання з великою кількістю слухачів, автоматизуючи при цьому весь навчальний процес від початку курсів підвищення кваліфікації до видачі електронного сертифікату, який підтверджуватиме здобуті знання.

На наш погляд, лідером серед популярних платформ дистанційного навчання $€$ платорорма Moodle (модульне об'єктно-орієнтоване динамічне навчальне середовище).

Відповідно до вимог, методів та змісту навчання освітні послуги Навчально-наукового інституту неперервної освіти НПУ імені М.П. Драгоманова спроектовані в системі Moodle 3 урахуванням досягнень сучасної педагогіки, з акцентом на взаємодію між педагогічними працівниками (http:// www.do.ippk.npu.edu.ua.).

Система Moodle має ряд переваг. Так, платформа має багатий набір модулів-складників для курсів підвищення кваліфрікації педагогічних працівників закладів дошкільної освіти - Чат, Опитування, Форум, Глосарій, Робочий зошит, Тест, Анкета, Scorm, Survey, Wiki, Семінар, Ресурс (у вигляді текстової або веб-сторінки або у вигляді каталогу).

Крім того, система надає можливість здійснити аналіз участі та активності слухачів курсу; аналіз часу, відведеного на роботу з матеріалами; оцінку труднощів, які виникли у групі (або даного слухача) під час опанування того чи іншого модуля; швидко надати допомогу під час навчальної роботи слухачів у мережі Інтернет чи локальній мережі закладу післядипломної освіти шляхом завантаження додаткових матеріалів.

Можливості платформи забезпечують і комунікаційну взаємодію слухачів курсів як у синхронному режимі за допомогою чату (учасникам навчального процесу необхідно мати доступ до мережі в один і той самий час), так і в асинхронному режимі за допомогою фроруму, e-mail, робочого зошиту тощо (одночасний доступ до мережі не потрібен). Чат використовується викладачами Інституту згідно з графріком навчального процесу, на дистанційному етапі, з метою «живого» спілкування. Форум проводиться у формі семінару, який розтягнутий у часі, та консультацій, як на дистанційному етапі курсового навчання, так і в міжкурсовий період для обговорення актуальних питань.

Натепер кожна з розглянутих систем дистанційного навчання має свої переваги та недоліки, реалізує важливі для електронного навчання фрункції, але не всі забезпечують процес дистанційного навчання в комплексі. На наш погляд, найголовнішими критеріями під час вибору інструментів для організації дистанційного навчання в системі післядипломної освіти мають бути відповідність методичним цілям, універсальність, зрозумілість інтерорейсу, доступність програмних засобів для різних пристроїв (персональні комп'ютери, планшети, мобільні пристрої Apple, Android тощо).

Висновки. Сучасні мережні технології спонукають педагогічного працівника закладу дошкільної освіти адаптуватися до загальносвітових тенденцій розвитку освітньої системи, бути здатним брати участь у створенні та впровадженні нового змісту освіти, нести відповідальність за результати своєї діяльності. Найбільш перспективним і цілеспрямовано організованим середовищем для розвитку IK компетентності педагогів закладів дошкільної освіти є система післядипломної педагогічної освіти.

Перспективами подальших досліджень є створення авторського сайту як платформи для розвитку ІК-компетентності педагогічних працівників закладів дошкільної освіти.

\section{БІБЛІОГРАФІЧНИЙ СПИСОК:}

1. Про Основні засади розвитку інорормаційного суспільства в Україні на 2007-2015 роки № 537-V від 09.01.2007 р. URL: http://zakon4.rada.gov.ua/laws/ show/537-16

2. Положення про дистанційне навчання від 25.04.2013 р. № 466, зареєстрованого в Міністерстві юстиції України 30 квітня 2013 р. за № 703/23235.

3. Семчук C.I. Психолого-педагогічні аспекти ефективного застосування комп'ютерних технологій у процесі навчання майбутніх фрахівців в галузі дошкільної освіти. Психолого-педагогічні проблеми сільської школи. 2012. № 42. С. 31-38.

4. Що таке платформа дистанційного навчання. URL: http://www.webostudio.com/ua/stats/whatissite

5. Сисоєва С.О., Осадча К.П. Системи дистанційного навчання: порівняльний аналіз навчальних можливостей. URL: http://www.academia.edu/931578. 